\title{
REDUCTION OF MORBIDITY IN HEPATOSPLENIC SCHISTOSOMIASIS MANSONI AFTER TREATMENT WITH PRAZIQUANTEL: A LONG TERM STUDY
}

\author{
Ana Lúcia C. Domingues and Amaury D. Coutinho
}

\begin{abstract}
Forty-two with hepatosplenic patients treated with praziquantel and followed up for 5 years. One half of the patients received a single $30 \mathrm{mg} / \mathrm{kg}$ dose and the other half, two doses of $25 \mathrm{mg} / \mathrm{kg}$ given $4 \mathrm{hrs}$ apart. According to Hoffman and Kato-Katz stool exams, an $83.3 \%$ cure rate, was observed after twelve months. Stool egg counts in cases of incomplete cure were greatly reduced. Liver function, as assessed by serum levels of aspartate aminotransferase, alanine aminotransferase, gamma glutamyltransferase and alkaline phosphatase activities as well as albumin and gamma globulin showed marked improvement after one year. Hepatomegaly was reduced in $81.0 \%$ of patients and splenomegaly in $78.8 \%$. Spleen regression was complete in $15.1 \%$ of the total, and in $18.5 \%$ of those with compensated hepatosplenic disease. As a result of these observations, the authors recomend early treatment with anti-schistosomal medication, either oxamniquine or praziquantel, to halt progression of disease and reduce splenomegaly.

Key-words: Hepatosplenic schistosomiasis mansoni. Treatment. Reversion.
\end{abstract}

Specific treatment of patients with hepatosplenic schistosomiasis (HS) has been the subject of many therapeutic trials including those using antimony 2532 , Niridazole ${ }^{12}$, hycanthone ${ }^{15}$, oxamniquine $e^{6} 13151819$ and praziquantel 41633 . Results have often been favourable though most post-treatment periods of observation have been limited to the short term.

The object of this investigation was to study the effect of praziquantel chemotherapy on HS schistosomiasis, by assessing long-term therapeutic efficacy and clinical response using tests of liver function, regression in hepatomegaly/splenomegaly and stool egg counts.

\section{MATERIAL AND METHODS}

Forty-two patients with chronic hepatosplenic schistosomiasis were treated in the Hospital das Clinicas of the Universidade Federal of Pernambuco. These patients came from areas in the Northeast of Brazil (States of Pernambuco and Alagoas) where schistosomiasis mansoni is hyperendemic.

Twenty-one of the patients were given a single oral $30 \mathrm{mg} / \mathrm{kg}$ dose of praziquantel; the other half, two doses of $25 \mathrm{mg} / \mathrm{kg}$, each given four hours apart.

Department of Internal Medicine of the Universidade Federal of Pernambuco, Recife, PE, Brazil.

Endereço para correspondência: Dr. Amaury D. Coutinho. Centro de Pesquisas "Aggeu Magalhães",/FIOCRUZ. CP: 7472 - 50730 Recife, PE, Brasil.

Recebido para publicação em 21/06/90.
Thirty-one of the patients were females; eleven were males. In endemic areas, in Northeast Brazil females tend to predominate among HS patients. Ages of the patients ranged from ten to forty-six, with an average age of twenty-four, and a standard deviation of about three years (Table 1).

Table 1 -Age distribution and mean numher of eggs in stool in 42 patients with schistosomiasis mansoni.

\begin{tabular}{ccrc}
\hline Age Range & N. patients & \multicolumn{1}{c}{$\%$} & $\begin{array}{c}\text { Mean number of } \\
\text { eggs/g feces }\end{array}$ \\
\hline $10-19$ & 13 & 30.95 & 2,768 \\
$20-29$ & 17 & 40.48 & 2,484 \\
$30-39$ & 10 & 23.81 & 613 \\
$40-46$ & 2 & 4.76 & 152 \\
Total & $42^{*}$ & 100.00 & \\
\hline
\end{tabular}

* Average age: $24 \mathrm{y} ; \mathrm{S}-2.75$

Thirty-two of the 42 patients had compensated hepatosplenic schistosomiasis (CHS). The other 10 had more advanced or complicated clinical variants 14 .

Patients came to the Outpatient Clinic one, three, six and twelve months after treatment, and thereafter once a year, for a total of five years. All patients were examined by the same investigator (A.L.C.D.). The left lobe of the liver was measured in centimeters from the xyphoid appendix to its greatest palpable dimension in the mid-sternal line. The spleen was measured in centimeters from the left rib margin, 
Domingues ALC, Coutinho AD. Reduction of morbidity in hepatosplenic schistosomiasis mansoni after treatment with praziquantel: a long term study. Revista da Sociedade Brasileira de Medicina Tropical 23:101-107, abr-jun, 1990

in the mid-clavicular line, to the point of its maximal palpable dimension.

Parasitological exam of the feces was always carried out by the same laboratory technician, Maria Eliete Fernandes, using the Hoffman sedimentation technique 20 and the Kato quantitative method as modified by Katz and others 22 . Counts of $S$. mansoni eggs per gram of feces were averaged from three different parts of the same faecal sample.

Liver function was assessed by measuring aspartate aminotransferase (AST), alanine aminotransferase (ALT), gammaglutamyl transferase (YGT) and alkaline phosphatase (AP) activities in serum using an optimized kinetic method at $25^{\circ} \mathrm{C}$. Bilirubin, both total and direct fraction (BT, BD) were measured by the Mallory-Evelyn technique; bromosulphalein (BSP) retention by Seligson's technique, with quantitation performed 45 minutes after introduction of $5 \mathrm{mg} / \mathrm{kg}$ of dye. Serum proteins were quantitated by electrophoresis using an alkaline sodium Veronal buffer, $\mathrm{pH}$ 8.6 from a Ponceau-stained cellulose acetate strip.

Statistical methods were the Students' $t$ and Wilcoxon test, taking 0.05 as level of significance.

\section{RESULTS}

\section{Therapeutic efficacy}

The mean number of eggs in stool, pre-treatment, was much higher among the 10-19 and 20-29 year age groups (Table 1). The distribution of patients according to pre-treatment egg count is showed in Table 2. Twenty-two patients, or $52.4 \%$ of the total, had over one thousand egg/gram of feces.

Table 2-Distribution of patients according to egg count before treatment.

\begin{tabular}{ccc}
\hline $\begin{array}{c}\text { No of eggs per } \\
\text { gram of feces* }\end{array}$ & No of cases & \% Total \\
\hline less than 100 & 4 & 9.52 \\
$100-500$ & 11 & 26.19 \\
$501-1,000$ & 5 & 11.90 \\
$1,001-5,000$ & 16 & 38.10 \\
more than 5,000 & 6 & 14.29 \\
Total & 42 & \\
\hline
\end{tabular}

* Geometric mean of three counts by the Kato-Katz technique.

The number of patients available for follow up is shown in Table 3. Along with cure-rates for each corresponding period of observation. Unfortunately most patients were lost for follow up after the first year due to the moving the "Hospital das Clínicas" to a new building far from the old one.
Table 3 - Cure rate at different time periods after treatment $2 \quad$ with praziquantel.

\begin{tabular}{cccc}
\hline \multirow{2}{*}{ Period } & \multicolumn{2}{c}{ No patients } & Cure rate \\
& Examined & Negative & $\%$ \\
\hline 3 months & 37 & 35 & 94.6 \\
6 months & 40 & 35 & 87.5 \\
12 months & 42 & 35 & 83.3 \\
5 years & 9 & 9 & 100.00 \\
\hline
\end{tabular}

Seven patients who were not completely cured showed a marked reduction in stool egg counts six or twelve months after praziquantel treatment (Table IV). Patients RJS and ASM, the youngest of the seven patients not cured had the lowest reduction in egg count.

Table 4-Relationship of patient age to reduction in egg counts in patients not cured after therapy.

\begin{tabular}{|c|c|c|c|c|c|}
\hline \multirow{2}{*}{ Patient } & \multirow{2}{*}{ Age } & \multicolumn{2}{|c|}{ Mean number of eggs } & \multirow{2}{*}{$\begin{array}{c}\% \\
\text { Reduction }\end{array}$} & \multirow{2}{*}{$\begin{array}{c}\text { Control } \\
\text { period } \\
\text { (months) }\end{array}$} \\
\hline & & Before & After & & \\
\hline$\overline{\mathrm{MJA}}$ & 23 & $15,712^{*}$ & 64 & 99.6 & 6 \\
\hline MJFS & 20 & 5,556 & 152 & 97.3 & 6 \\
\hline EAF & 14 & 2,768 & 16 & 94.4 & 6 \\
\hline EAF & 13 & 3,512 & 96 & 97.3 & 6 \\
\hline JMS & 13 & 8,345 & 360 & 95.7 & 12 \\
\hline RJS & 12 & 1,048 & 208 & 80.1 & 12 \\
\hline ASM & 12 & 664 & 144 & 78.3 & 6 \\
\hline
\end{tabular}

* Probable reinfection. Second treatment.

All patients not cured initially received a second course of praziquantel at the same dosage, six to twelve months after the first one. All become stool negative after the second treatment.

\section{Liver function tests}

Table 5 shows the results of the liver function tests, before treatment and one year later. Statistically significant changes occurred with AST, ALT, AP and gamma globulin (Y GLOB).Albumin (ALB) levels increased significantly. However, YGT, BSP, BT and BD showed no changes.

Six patients had individual AST values of over 40 IU before treatment. One year later, only one had an elevated level. Two had ALT values over $50 \mathrm{IU}$ before treatment. One year later both patients had normal levels of activity.

Twenty out of 33 patients, $60.6 \%$, had individual AP values over 200 IU before treatment. One 
Domingues ALC, Coutinho AD. Reduction of morbidity in hepatosplenic schistosomiasis mansoni after treatment with praziquantel: a long term study. Revista da Sociedade Brasileira de Medicina Tropical 23:101-107, abr-jun, 1990

Table 5 - Mean values of Aminotransferase (AST), Alanine aminotransferase (ALT), Alkaline phosphatase (AP), Albumin (ALB), Gamma globulin (Y Glob), Gammaglutamyl transferase (Y GT), Bilirubin (BT) and Bromosulphalein $(B S P)$ before and in the first year after treatment.

\begin{tabular}{lccrcc}
\hline Test & $\begin{array}{c}\text { No of } \\
\text { cases }\end{array}$ & $\begin{array}{c}\text { Before } \\
\text { treatment }\end{array}$ & $\begin{array}{c}\text { After } \\
\text { treatment }\end{array}$ & Test & Statistical \\
\hline AST & 34 & 21.97 & 16.94 & Wilcoxon & 0.020 \\
ALT & 34 & 19.70 & 15.91 & Wilcoxon & 0.032 \\
AP & 29 & 313.95 & 268.72 & Wilcoxon & 0.0075 \\
ALB & 35 & 3.28 & 3.53 & t student & 0.001 \\
Y Glob & 35 & 2.43 & 2.01 & t student & 0.01 \\
YGT & 22 & 23.03 & 23.34 & Wilcoxon & 0.050 \\
BT & 32 & 0.81 & 0.88 & Wilcoxon & 0.229 \\
BD & 32 & 0.30 & 0.28 & Wilcoxon & 0.850 \\
BSP & 22 & 5.61 & 6.56 & Wilcoxon & 0.106 \\
\hline
\end{tabular}

Normal values: AST: 5-17 IU. ALT: 5-23 IU. AP: 40-190 IU. YGT: 6-28 IU. BSP: 6\% or less dye retention.

year after, 15 out of 29 or $51.7 \%$, still had elevated values.

Ten individuals had elevated Y GLOB values between $2.5 \mathrm{dl}$ and $3.0 \mathrm{dl}$ one year later five out of these 10 patients had normal values. In addition, six other patients had values greater than $3.0 \mathrm{dl}$; one year later, only two of these six patients had abnormal values.

Four patients had individual ALB levels under $2.5 \mathrm{dl}$ before treatment; one year later, none were below that level. Ten had ALB levels between $2.5 \mathrm{dl}$ and $3.0 \mathrm{dl}$ before treatment; one year later, only four were below $3.0 \mathrm{dl}$.

Individual Y GT values varied widely, both before and after treatment. In nearly every case, BT,
BD and BSP values were normal or near-normal before and after chemotherapy.

\section{Reduction of hepatomegaly and splenomegaly}

As shown in Table 6, liver size was reduced in $81.0 \%$ of patients after one year though only nine of 42 patients could be followed through the fifth year. Liver size was reduced in eight of these nine patients. Comparison of average liver size before treatment with level size one year and five years later (Table 7) showed statistically significant reduction during the follow-up period. No patient, however, had complete regression to normal.

Table 6-Evolution of liver and spleen size in the first and fifth year after treament.

\begin{tabular}{|c|c|c|c|c|c|c|c|c|}
\hline \multirow[b]{2}{*}{$\begin{array}{l}\text { Change } \\
\text { in size }\end{array}$} & \multicolumn{3}{|c|}{ First year } & \multirow[b]{2}{*}{$\%$} & \multicolumn{3}{|c|}{ Fifth year } & \multirow[b]{2}{*}{$\%$} \\
\hline & $\begin{array}{l}\text { Liver } \\
\text { No }\end{array}$ & $\%$ & $\begin{array}{c}\text { Spleen } \\
\text { no }\end{array}$ & & $\begin{array}{l}\text { Liver } \\
\text { No }\end{array}$ & $\%$ & $\begin{array}{l}\text { Spleen } \\
\text { No }\end{array}$ & \\
\hline None & 8 & 19.0 & 7 & 21.21 & 1 & 11.1 & 2 & 33.3 \\
\hline Decrease & 34 & 81.0 & 26 & 78.8 & 8 & 88.9 & 4 & 66.7 \\
\hline Total & 42 & - & $33^{+}$ & - & 9 & - & $6^{++}$ & - \\
\hline
\end{tabular}

+ Nine and ++ three patients had undergone splenectomy.

As shown in Table 6 reduction of splenomegaly occurred in $78.8 \%$ of the patients one year after chemotherapy. In five of the 42 patients studied (15.1\%), reduction was complete and the spleen was no longer palpable. After five years, four out of six had smaller spleens (Table 6). Statistically significant reduction in average spleen size was detected one and five years after treatment (Table 7).
There was no correlation between hepatomegaly or splenomegaly reduction and patient age, degree of infection, Y GLOB and AP levels.

\section{Effect of treatment on other clinical forms}

Treatment was well tolerated in the 32 compensated HS patients. None showed signs of worse- 
Domingues $A L C$, Coutinho AD. Reduction of morbidity in hepatosplenic schistosomiasis mansoni after treatment with praziquantel: a long term study. Revista da Sociedade Brasileira de Medicina Tropical 23:101-107, abr-jun, 1990

Table 7 - Mean values and standard deviation of liver and spleen size in centimeters, before treatment, one year and five years after praziquantel.

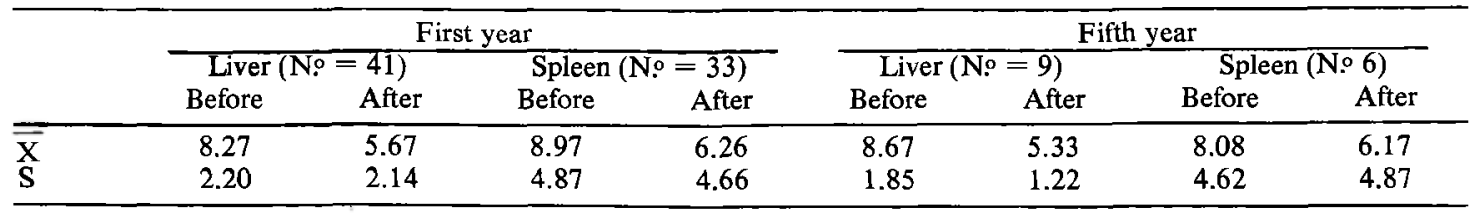

First year. Wilcoxon $p<0.00003$; Fifth year. Wilcoxon for the liver: $p<0.01$.

ning of the disease after treatment. Five had been splenectomised before treatment. Of the remaining twenty seven, five or $18.5 \%$ had a spleen which was no longer palpable after treatment. That is, there was regression to the hepato-intestinal stage.

Seven of the 42 patients studied has a history of upper gastro-intestinal hemorrhage before praziquantel treatment, five had hematemesis, two had melena. Bleeding recurred in three of the seven, $42.9 \%$, after chemotherapy. Four of $35(11.4 \%$ ) who had no hemorrhage before treatment had gastrointestinal hemorrhage after treatment. These diferences were statistically significant.

One HS case demonstrated marked growth retardation. At age sixteen he was $1 \mathrm{~m} 29 \mathrm{~cm}$ tall, and weighed only $28.5 \mathrm{~kg}$. Two years after praziquantel treatment he had grown $12 \mathrm{~cm}$, and put on $8 \mathrm{~kg}$.

In another case, HBsAg was detected in the blood before treatment. Two years after treatment there was no change in liver function parameters and HBS Ag was still present. A liver biopsy 10 months after treatment showed persistent chronic hepatitis and moderate portal fibrosis.

Among the remaining 10 more complicated patients, five had the so-called intermediate or transitional HS form ${ }^{14}$. In this $\mathrm{HS}$ form, patients have transitory symptoms of hepatic decompensation, such as oedema and ascites, which regress with supportive clinical therapy. These patients did not show further clinical deterioration after praziquantel treatment. However, liver function tests did not return completely to normal, as the AST, ALT, BT, BD, BSP and Y GLOB remained mildly abnormal and ALB remained under $3 \mathrm{~g} \%$.

One fourteen-year-old patient had prolonged fever and diarrhea before treatment. A hemoculture showed Salmonella sp. He was treated with antibiotics, then praziquantel. His response was satisfactory.

Three cases had in addition to HS, the hypertensive cardio-pulmonary complication and another patient had the cyanotic form of Schistosomiasis. Two of the three patients had severe pulmonary arterial hypertension with signs and symptoms of cardiac insufficiency, which were not affected by specific treatment. One died of cardiac insufficiency eighteen months after treatment. The third patient, with moderate pulmonary hypertension, gradually improved over a 2.1/2 year period of observation.

An eighteen-year-old patient with the cyanotic form showed, by the end of the first year, a significant reduction in spleen size, and in cyanosis.

\section{DISCUSSION}

After twelve months of follow-up, $83.0 \%$ of the patients had no eggs in their stools in the present study. Note that our patients live in an area of hyperendemic schistosomiasis, and are often highly infected (see Table 2), especially under 30 years of age (Table 1 ). All but one of the seven who were not completely cured were heavily infected before treatment with over 1,000 eggs/g of faces (Table 4). This inverse relationship between percentage of cure rate and degree of infection had previously been observed by Prata et al. 29 Consistent with results of others 2335 we found that young patients had lower cure rates and lower reduction in egg counts (Table 4). This indicates that children need larger doses, at least $60 \mathrm{mg} / \mathrm{kg}$ of praziquantel.

Four patients who failed therapy were administered repeat doses of praziquantel and were cured six months later. We believe that second treatment after six months is sufficient. Cunha et al. ${ }^{17}$ however, hold an alternative view. They administered praziquantel $(60 \mathrm{mg} / \mathrm{kg}$ each day) for three days, measuring cure rates by rectal biopsy, which they believe to be more accurate.

One case deserves special mention. A twentythree-year-old woman had a pretreatment egg count of 2,456 . She did not appear for parasitological checks at three and six months. She underwent splenectomy nine months after treatment. At twelve months, her KatoKatz. stool egg count was 15,712 eggs/g. She had gone back to an hyperendemic area and to its contaminated waters. Such epidemiological evidence and the higher egg count, are definitive signs of intense reinfection. 
Domingues ALC, Coutinho AD. Reduction of morbidity in hepatosplenic schistosomiasis mansoni after treatment with praziquantel: a long term study. Revista da Sociedade Brasileira de Medicina Tropical 23:101-107, abr-jun, 1990

Usually, patients, if reinfected, have low egg counts 7 21. This usually high level may be due to the splenectomy after praziquantel treatment which may have changed her immunological response. After a further dose of praziquantel, she immediately exhibited symptoms of coughing, dyspnea, wheezing and abdominal pain. We have in a previous study ${ }^{11}$ referred to this as a hypersensitivity reaction to dead parasite antigens after treatment in some patients.

There have been few long-term studies of liver function in man after schistosomiasis chemotherapyl3 $1628 \quad 32$. In the present study we report significant reductions in pre-treatment AST, ALT, Y GT, AP, and Y GLOB and an increase in serum ALB. This evidence of improvement in liver function may well be due to a reduction in schistosomiasis hepatic inflamatory response after treatment, as has been observed in mice infected with $S$. mansoni 3136 and in chimpanzees with $S$. japonicum ${ }^{30}$. But improved liver function may also be due to regression of schistosomiasis intra-hepatic vascular lesions, as has been seen in mice after chemotherapy ${ }^{3}$.

Experiments in animals, mainly mice, had shown the beneficial effects of specific treatment in prevention and reversion of hepatosplenomegaly, portal hypertension and hepatic fibrosis $8927 \quad 36$. Similarly studies in man, have shown good results with different drugs on prevention and regression of hepatosplenomegaly, during short periods of observation $^{6} 1318$. Analysis of our results show reduction in liver size in $81.0 \%$ of cases one year after treatment, and of spleen size in $78.8 \%$. Reduction in spleen size was complete in $15.1 \%$ of the total of cases, and in $18.5 \%$ of compensated HS patients. In our previous studies with oxamniquine and prazinquantel, regression of liver and spleen was less marked after six months: $50.3 \%$ and $62.1 \%$ for the liver, 53.5 and $57.4 \%$ for the spleen ${ }^{13} 16$. Also, during the first six months after treatment, no cases of complete regression of splenomegaly were observed. On the other hand, as Tables VI and VII show, hepatosplenic regression, in the few cases followed up to five years, was similar to one year of observation. Thus, our data would indicate that hepatosplenic regression following specific therapy needs an extended period of observation: one year at least.

Our data is similar to observations recently published by Bina and Prata ${ }^{6}$ in younger patients and by Dietze and Prata ${ }^{18}$ in patients with milder degrees of splenomegaly. In fact, in the five cases in our study with total regression of the spleen, spleen size before treatment was between $3.5 \mathrm{~cm}$ and $5 \mathrm{~cm}$. This suggests that the smaller the spleen size the greater the chance of complete regression.
However, we observed in our present study, as did Dietze and Prata 18 that even older patients of forty-one and forty-six years of age could show a reduction of hepatosplenomegaly. Furthermore, there was a thirty-nine-old among our five cases of complete splenic regression. We suggest therefore that specific chemotherapy should be administered to all HS patients in whom no special contra indications apply. The effects of treatment should be observed for at least twelve months before any eletive surgery is contemplated, with exception of cases with history of gastrointestinal hemorrhage (see later).

We observed no correlation between reduction of hepatomegaly or splenomegaly and degree of infection. This lack of correlation agrees with the findings of Bina and Prata ${ }^{6}$. We found the same lack of correlation with respect to Y GLOB and AP, commonly believed to be good indicators of active hepatic schistosomiasis.

Also noteworthy is the high level of parasite infection frequently recorded in our HS patients, $52.4 \%$ of whom had a test count of over 1.000 eggs/gram of feces. This phenomenon had already been recorded as far back as 1962 by Kloetzel 24 , and had been confirmed by others 102634 . This relationships between degree of schistosomiasis infection and development of hepatomegaly has been more marked in younger patients (see Table 1 and 3 and Katz et $\mathrm{al}^{23}$, Sturroch et al. ${ }^{35}$ This relationship, however, does not always apply in all situations. We noted in the present study, for example, cases with markedly enlarged spleens, yet with low Kato-Katz counts, Kloetzel 2425 in field studies, has already drawn attention to the sharp drop in egg counts in the feces of children between ten and fourtheen, coinciding with the development of splenomegaly.

In the present study, we followed one case in which there was marked improvement in growth after specific treatment. Such improvement was previously observed by us 13 after treatment with other antischistosomiasis drugs, such as oxamniquine, and had also been observed by Bina and Prata ${ }^{6}$.

Gastrointestinal hemorrhage was more common after treatment in those patients who had suffered from bleeding before treatment than it was in those who had no bleeding. This would seem to indicate that specific schistosomiasis treatment alone does not prevent digestive bleeding. It is our opinion, then, that cases showing gastrointestinal hemorrhage should undergo surgery or endoscopic treatment of the oesophagogastric varices, either before or after specific treatment, depending on the conditions in each individual case. 
Domingues $A L C$, Coutinho AD. Reduction of morbidity in hepatosplenic schistosomiasis mansoni after treatment with praziquantel: a long term study. Revista da Sociedade Brasileira de Medicina Tropical 23:101-107, abr-jun, 1990

In our most advanced cases of HS, where hepatic decompensation was present, as well as in those with the fully-developed cardiopulmonary form, we found little or no clinical improvement after specific chemotherapy. This finding has already been referred to in clinical and experimental studies by Warren \& Klein ${ }^{37}$; Sadun et al. ${ }^{30}$; Coutinho \& Domingues ${ }^{13}$ and Almeida \& Andrade 2 .

From observations made in the present study, from our previous observations, and from those of our colleagues, we recommend that specific antischistosomal treatment with either oxamniquine or praziquantel, should be administered, as soon as possible, except when there are special contraindications. We recommend prompt treatment, particularly in cases of children and teenagers with high levels of infection to arrest the progress of the disease. Even when the stage of the disease is advanced, specific treatment, which is generally well tolerated, should be tried, as some beneficial effect may follow. In addition no deterioration in the condition of the patient due to treatment with either oxamniquine or praziquantel has been observed.

\section{RESUMO}

Quarenta e dois pacientes esquistossomóticos hepatosplênicos, tratados com praziquantel, foram acompanhados por cinco anos. Metade dos pacientes recebeu uma dose simples de $30 \mathrm{mg} / \mathrm{kg}$; a outra metade, recebeu duas doses de $25 \mathrm{mg} / \mathrm{kg}$ dadas com intervalos de 4 horas. A taxa de cura, de acordo com os exames de fezes pelos métodos de Hoffman cols e de Kato-Katz, durante 12 meses foi de 83,3\%. Nos casos com cura incompleta, os ovos contados nas fezes foram muito reduzidos. A função hepática, estimada pelo nível, no soro, de aspartato aminotransferase, alamina aminotransferase, gama glutamiltransferase e fosfatase alcalina bem como, de albumina e gama globulina mostrou acentuada melhora após um ano. Hepatomegalia foi reduzida em $81,0 \%$ dos pacientes e esplenomegalia em $78,8 \%$. A regressão do baço foi completa em $15,1 \%$ do totale em $18,5 \%$ daqueles com forma hepatosplênica compensada. Como resultado destas observafões, os autores recomendam tratamento precoce com medicação antiesquistossomótica com oxamniquine ou praziquantel para interromper a progressão da doença e reduzir hepatomegalia e esplenomegalia.

Palavras-chaves: Esquistossomose mansoni hepatosplênica. Tratamento. Reversão.

\section{REFERENCES}

1. Abdallah A, Saif M, Koura M. The role of chemotherapy in the control of schistosomiasis: experience in Egypt. Brasilia Médica 11:49-54, 1975.
2. Almeida MAC, Andrade ZA. Effect of chemotherapy on experimental pulmonary schistosomiasis. The American Journal of Tropical Medicine and Hygiene 32:10491054, 1983.

3. Andrade ZA, Brito PA. Evolution of schistosomal hepatic vascular lesions after specific chemotherapy. The American Journal of Tropical Medicine and Hygiene 30:1223-1227, 1981.

4. Bassily S, Farid Z, Dunn M, el-Masry NA, Stek Jr M. Praziquantel for treatment of schistosoniasis in patients with advanced hepatosplenomegaly. Annals of Tropical Medicine and Parasitology 79:629-634, 1985.

5. Bina JC, Prata A. Possibilidade de prevenção das formas graves da esquistossomose mansoni: papel da terapêutica especifica. In: Prata A (ed) Situação e Perspectivas do controle das doenças infecciosas e parasitárias. Editora Universidade de Brasilia, Brasília, p. 45-56, 1981.

6. Bina JC, Prata A. Regressão da hepatosplenomegalia pelo tratamento específico da esquistossomose. Revista da Sociedade Brasileira de Medicina Tropical 16:213$218,1983$.

7. Butterworth AE, Capron M, Cordingley JS, Daiton PR, Dunne DW, Kariuki HC, Kimani G, Koech D, Mugambi M, Ouma JH, Prentice MA, Richardson BA, Arap Siongok TK, Sturrock RF, Tayla DW. Immunity after treatment of human schistosomiasis mansoni. II Identification of resistant individuals and analysis of their immune responses. Transactions of the Royal Society of Tropical Medicine and Higyene 79:393-408, 1985.

8. Cameron GR, Ganguly NC. An experimental study of the pathogenesis and reversibility of schistosomal hepatic fibrosis. The Journal of Pathology and Bacteriology 87:217-237, 1964.

9. Cheever AW, Dewitt WB, Warren KS. Repeated infection and treatment of mice with Schistosoma mansoni: functional, anatomic and immunologic observations. The American Journal of Tropical Medicine and Hygiene 14:239-253, 1965.

10. Cook JA, Baker ST, W arren KS, Jordan P. A controlled study of morbidity of Schistosomiasis mansoni in St. Lucian children, based on quantitative egg excretion. The American Journal of Tropical Medicine and Hygiene 23:625-633, 1974.

11. Coutinho A. Clinical laboratory manifestations due to the death of worms after specific treatment of Schistosomiasis. Brasilia Médica 11:69-80, 1975.

12. Coutinho A, Barreto FT. Treatment of hepatosplenic schistosomiasis mansoni with niridazole: relationships among liver function, effective dose and side effects. Annals of the New York Academy of Sciences 160:612$628,1969$.

13. Coutinho A, Domingues ALC. Evaluation of the treatment of severe forms of schistosomiasis mansoni with oxamniquine. Revista do Instituto de Medicina Tropical de São Paulo 22 (Supl. 4):41-51, 1980.

14. Coutinho A, Domingues ALC. Esquistossomose mansoni. In: Dani R, Paula Castro L (ed). Gastroenterologia Clínica, (2a edição). Guanabara Koogan, Rio de Janeiro, p. 1361-1386, 1988. 
Domingues ALC, Coutinho AD. Reduction of morbidity in hepatosplenic schistosomiasis mansoni after treatment with praziquantel: a long term study. Revista da Sociedade Brasileira de Medicina Tropical 23:101-107, abr-jun, 1990

15. Coutinho A, Domingues ALC, Bonfim JR. Treatment of schistosomiasis mansoni with oxamniquine. Revista do Instituto de Medicina Tropical de São Paulo 15:15-34, 1973.

16. Coutinho AD, Domingues ALC, Florêncio JN, Almeida ST. Tratamento da esquistossomose mansônica hepatosplênica com praziquantel. Revista do Instituto de Medicina Tropical de São Paulo 26:38-50, 1984.

17. Cunha AS, Cançado JR, Rezende GL. Therapeutical evaluation of different dose regimens of praziquantel in Schistosomiasis mansoni, based on the quantitative oogram technique. Revista do Instituto de Medicina Tropical de São Paulo 29:295-304, 1987.

18. Dietze R, Prata A. Rate of reversion of hepatosplenic schistosomiasis after specific therapy. Revista da Sociedade Brasileira de Medicina Tropical 19:69-73, 1986.

19. Farid Z, Higashi GI, Bassily S, Trabolsi B, Watten RH. Treatment of advanced hepatosplenic schistosomiasis with oxamniquine. Transactions of the Royal Society of Tropical Medicine and Hygiene 74:400-401, 1980.

20. Hoffman WA, Pons JA, Janer JL. The sedimentation concentration method in Schistosomiasis mansoni. Puerto Rico. Journal of Public Health and Tropical Medicine 9:283-291, 1934.

21. Katz N. Experiências com quimioterapia em grande escala no controle da esquistossomose no Brasil. Revista do Instituto de Medicina Tropical de São Paulo 22:40$51,1980$.

22. Katz N, Chaves A, Pellegrino J. A simples device for quantitative stool thick smear technique in Schistosomiasis mansoni. Revista do Instituto de Medicina Tropical de São Paulo 14:397-400, 1972.

23. Katz N, Zicker F, Rocha RS, Oliveira VB. Re-infection of patients in schistosomiasis mansoni endemic areas after specific treatment. I-Influence of age and worm burden. Revista do Instituto de Medicina Tropical de São Paulo 20:273-278, 1978.

24. Klöetzel K. Splenomegaly in Schistosomiasis mansoni. The American Journal of Tropical Medicine and $\mathrm{Hy}-$ giene 11:472-476, 1962.

25. Klöetzel K. A suggestion for the prevention of severe clinical forms of schistosomiasis mansoni. Bulletin of the World Health Organization 37:686-687, 1967.

26. Lehman JS, Mott KE, Morrow Jr RH, Muniz TM, Boyer MH. The intensity and effects of infection with Schistosoma mansoni in a rural community in Northeast Brazil. The American Journal of Tropical Medicine and $\mathrm{Hy}$ giene 25:285-294, 1976.

27. Morcos SH, Khayyal MT, Mansour MM, Saleh S, Ishak EA, Girgis NI, Dunn MA. Reversal of hepatic fibrosis after praziquantel therapy of murine schistosomiasis. The American Journal of Tropical Medicine and $\mathrm{Hy}$ giene 34:314-321, 1985.

28. Mousa AH, Ata AA, El Rooby A, El Garem A, Abdel MF, El Raziky E. Clinics pathological aspects of hepatosplenic bilharziasis. In: FK Mostofi (ed) Bilharziasis. Spring Verlag, p. 15-29, 1967.

29. Prata A, Castro CN, Silva AE, Paiva M, Macedo V, Junqueira Jr LF. Praziquantel no tratamento da esquistossomose mansoni. Revista do Instituto de Medicina Tropical de São Paulo 24:95-103, 1982.

30. Sadun EH, Lichtenberg FV, Erickson DG, Cheever AW, Bueding EE, Anderson JS. Effects of chemotherapy on the evaluation of Schistosomiasis japonica in chimpanzees. The American Journal of Tropical Medicine and Hygiene 23:639-661, 1974.

31. Schiller EL, Haese WH. Histologic processes of healing in hepatic injury due to eggs of $S$. chistosoma mansoni in mice following curative chemotherapy. The American Journal of Tropical Medicine and Hygiene 22:211-214, 1973.

32. Sette H. O tratamento da esquistossomose mansoni à luz da patologia hepática. Thesis, Faculdade de Medicina de Pernambuco, Recife, 1953.

33. Silva LC, Sette $\mathrm{H}$, Christo $\mathrm{CH}$, Saez-Alquezar A, Carneiro CRW, Lacet CM, Ohtsuki N, Raid S. Praziquantel in the treatment of the hepatosplenic form of Schistosomiasis mansoni. Arzneimittel-Forschung Research 31(supl. 1):601-603, 1981.

34. Siongok TKA, Mahmoud AAF, Ouma JH, Warren KS, Muller AS, Handa AK, Houser HB. Morbidity in schistosomiasis mansoni in relation to intensity of infection: study of a community in Machakos, Kenya. The American Journal of Tropical Medicine and Hygiene 25:273-284, 1976.

35. Sturrock RF, Bensted-Smith R, Butterworth AE, Dalton PR, Kariuki HC, Koech D, Mugambi M, Ouma JH, Arap Siongok TK. Immunity after treatment of human schistosomiasis mansoni. III Long-term effects of treatment and retreatment. Transactions of the Royal Society of Tropical Medicine and Hygiene 81:303-314, 1987.

36. Warren KS, The influence of treatment on the development and course of murine hepatosplenic Schistosomiasis mansoni. Transactions of the Royal Society of Tropical Medicine and Hygiene 56:510-519, 1962.

37. Warren KS, Klein L. Chronic murine hepatosplenic schistosomiasis mansoni: relative irreversibility after treatment. 1 ransactions of the Royal Society of Tropical Medicine and Hygiene 63:333-337, 1969. 